\title{
BIOACTIVE PRINCIPLES OF THE FLOWERS OF PANCRATIUM MARITIMUM
}

\author{
Diaa T.A. Youssef
}

Department of Pharmacognosy, Faculty of Pharmacy, Suez Canal University, Ismailia 41522, Egypt

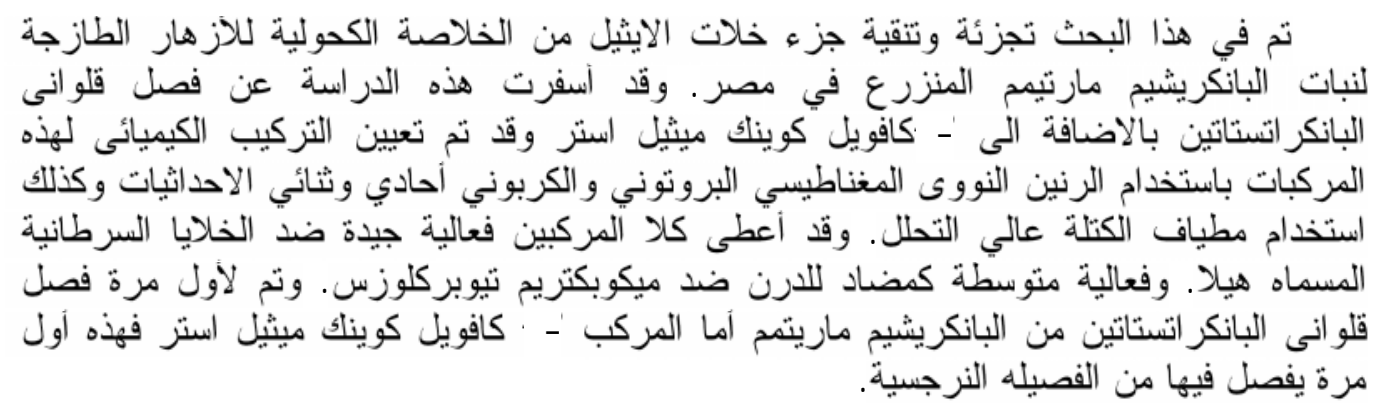

Bioactive-guided fractionation and purification of the ethyl acetate fraction of an ethanolic extract of fresh flowers of Pancratium maritimum (Amaryllidaceae) cultivated in Egypt yielded an alkaloid, pancratistatin (1), together with 3caffeoylquinic acid methyl ester (2). Their structures were determined on the basis of extensive $1 D\left({ }^{1} H\right.$ and $\left.{ }^{13} \mathrm{C}\right)$ and $2 D(C O S Y, H M Q C, H M B C$, and NOESY) NMR studies and high-resolution mass spectral measurements. Both compounds showed potent cytotoxic activity against HeLa cells and moderate anti-tuberculosis activity against Mycobacterium tuberculosis H37Rv. This is the first report of pancratistatin in Pancratium maritimum and the first report of 3-caffeoylquinic acid methyl ester in the family Amaryllidaceae.

\section{INTRODUCTION}

In continuation of our on going investigation and search for drug leads from the Egyptian Amaryllidaceae plants, ${ }^{1-6}$ we have investigated the fresh flowers of Pancratium maritimum and found that the ethyl acetate fraction of an ethanolic extract of the fresh flowers possesses cytotoxic activity against HeLa cells. Bioactive-guided fractionation and purification of the active fractions furnished two potent cytotoxic compounds namely pancratistatin (1) and 3-caffeoylquinic acid methyl ester (2) (Figure 1).

The structural determination of the isolated compounds was established using different spectroscopic techniques including UV, IR, HRFABMS, and $1 \mathrm{D}\left({ }^{1} \mathrm{H}\right.$ and $\left.{ }^{13} \mathrm{C}\right)$ and
2D ( ${ }^{1} \mathrm{H}-{ }^{1} \mathrm{H}$ COSY, HMQC, HMBC, and NOESY) NMR studies.

Pancratistatin is reported for the first time from the Egyptian Pancratium maritimum and this is the first report of 3-caffeoylquinic acid methyl ester in the family Amaryllidaceae. In addition, the tuberculostatic activity of both compounds is reported here for the first time.

Previous studies on different parts of the plant in our laboratory resulted in the isolation of alkaloids, chromones, chalcones, acetophenones, flavans, and flavonoids. ${ }^{2-6}$

The present work deals with the isolation, structural mapping and the biological (cytotoxic and anti-tuberculosis) evaluation of compounds $\mathbf{1}$ and $\mathbf{2}$. 


\section{EXPERIMENTAL}

\section{General experimental procedures}

Mps were uncorrected. Optical rotations were measured on JASCO DIP-1000 digital polarimeter. UV spectra were recorded on a Hitachi 300 spectrometer. ${ }^{1} \mathrm{H}$ and ${ }^{13} \mathrm{C}$ NMR spectra were recorded on a JEOL $\alpha-500$ spectrometer at $500 \mathrm{MHz}$ for ${ }^{1} \mathrm{H}$ and $125 \mathrm{MHz}$ for ${ }^{13} \mathrm{C}$, respectively. NMR chemical shifts were referenced to TMS as internal standard. Positive FAB mass spectral data were obtained with a JEOL JMS-700T mass spectrometer using 3-nitrobenzylalcohol (3-NBA) as matrix. HPLC was performed on preparative (ARII Cosmosil, $250 \times 20 \mathrm{~mm}$ ) and semipreparative (ARII Cosmosil, $250 \times 10 \mathrm{~mm}$ ) C18 columns (Waters) with a UV detector at $220 \mathrm{~nm}$ and flow rate of 5.5 or $2.0 \mathrm{~mL} / \mathrm{min}$. Precoated silica gel $60 \mathrm{~F}_{254}$ plates (E. Merck) were used for TLC.

\section{Plant material}

The fresh flowers of Pancratium maritimum were collected in May 2000 from the cultivated plants at the campus of Suez Canal University. The plant material was authenticated by Prof. Dr. A. Fayed, Professor of plant taxonomy at Assiut University. A voucher specimen was deposited in herbarium of the Department of Pharmacognosy, at Faculty of Pharmacy, Suez Canal University under the registration No. PM1.

\section{Extraction and isolation}

The fresh flowers $(6.85 \mathrm{~kg})$ were crushed into small pieces and macerated in ethanol 70 $\%(3 \times 10 \mathrm{~L})$ at room temperature. The combined extracts were evaporated under reduced pressure. The brown viscous residue was dissolved in $500 \mathrm{~mL}$ water and was successively extracted with n-hexane ( 3 x 250 $\mathrm{mL})(5.32 \mathrm{~g}), \mathrm{CH}_{2} \mathrm{Cl}_{2}(3 \times 250 \mathrm{~mL})(2.45 \mathrm{~g})$, ethyl acetate $(3 \times 250 \mathrm{~mL})(3.55 \mathrm{~g})$, and $\mathrm{n}$ butanol (3 x $250 \mathrm{~mL})(10.21 \mathrm{~g})$. Preliminary cytotoxicity assay on the crude fractions showed that the ethyl acetate fraction possesses cytotoxicity against $\mathrm{HeLa}$ cells. The ethyl acetate residue $(3.55 \mathrm{~g})$ was subjected to flash chromatography on ODS column $(40 \times 3.0 \mathrm{~cm})$ starting with $10 \% \mathrm{MeOH}$ in $\mathrm{H}_{2} \mathrm{O}$ through pure $\mathrm{MeOH}$ (each $500 \mathrm{~mL}$ ). The fraction eluted with $20 \% \mathrm{MeOH}$ showed moderate cytotoxicity
$\left(\mathrm{IC}_{50}=1.8 \mu \mathrm{g} / \mathrm{mL}\right)$ against HeLa cells. The residue of this fraction $(1.25 \mathrm{~g})$ was flash chromatographed on ODS column $(40 \times 3.0$ cm) starting with $\mathrm{H}_{2} \mathrm{O}$ through pure $\mathrm{MeOH}$ (each $500 \mathrm{~mL}$ ). The fractions eluted with $20 \%$ $\mathrm{MeOH}$ through $40 \% \mathrm{MeOH}$ showed similar TLC patterns and were cytotoxic $\left(\mathrm{IC}_{50}=0.8\right.$ $\mu \mathrm{g} / \mathrm{mL}$ ) to Hela cells. The residue of these fractions $(520 \mathrm{mg})$ was flash-chromatographed on ODS column $(30 \times 2.0 \mathrm{~cm})$ starting with $5 \%$ $\mathrm{MeOH}$ in $\mathrm{H}_{2} \mathrm{O}$ through pure $\mathrm{MeOH}$ (each 300 $\mathrm{mL})$. The fraction eluted with $15 \% \mathrm{MeOH}$ was potent cytotoxic $\left(\mathrm{IC}_{50}=0.08 \mu \mathrm{g} / \mathrm{mL}\right)$ to $\mathrm{HeLa}$ cells. This fraction $(118 \mathrm{mg})$ was finally purified on a preparative C18 HPLC column (ARII Cosmosil, $250 \times 20 \mathrm{~mm}$, Waters) using $30 \% \mathrm{MeCN}$ in $\mathrm{H}_{2} \mathrm{O}$ to afford 2 (10.9 $\mathrm{mg}$ ) and an impure 1 (48 mg). Compound 1 was further purified on a semi-preparative C18 HPLC column (ARII Cosmosil, 250 x $10 \mathrm{~mm}$, Waters) using $25 \% \mathrm{MeOH}$ in $\mathrm{H}_{2} \mathrm{O}$ to afford $17.8 \mathrm{mg}$ of pure 1.

Compound (1): White solid. m.p 323-325 ${ }^{\circ}$ $[\alpha]_{\mathrm{D}}^{25}=+48.6^{\circ}(\mathrm{DMSO}, c=0.1)$. UV $(\mathrm{MeOH})$ $\lambda_{\max }: 280,237 \mathrm{~nm}$. Positive HRFABMS: obsd $m / z 326.0879[\mathrm{M}+\mathrm{H}]^{+}$(calcd for $\mathrm{C}_{14} \mathrm{H}_{16} \mathrm{NO}_{8}$, 326.0876). $\operatorname{IR}(\mathrm{KBr}) v_{\max }: 3419,1672,1629$, 1468, 1358, 1083, $1047 \mathrm{~cm}^{-1} .{ }^{1} \mathrm{H}$ and ${ }^{13} \mathrm{C}$ NMR data are listed in Table 1.

Compound (2): Yellowish oil. UV (MeOH) $\lambda_{\max }: 329, \quad 298,235,219 \mathrm{~nm}$. Positive HRFABMS: obsd $\mathrm{m} / \mathrm{z} 369.1189[\mathrm{M}+\mathrm{H}]^{+}$ (calcd for $\left.\mathrm{C}_{17} \mathrm{H}_{21} \mathrm{O}_{9}, 369.1186\right)$. IR (KBr) $v_{\text {max }}$ : $3420,1664,1520,1163,1027,625 \mathrm{~cm}^{-1} .{ }^{1} \mathrm{H}$ and ${ }^{13} \mathrm{C}$ NMR data are listed in Table 2.

\section{RESULTS AND DISCUSSION}

\section{Compound 1}

Compound 1 was purified as white solid. The positive HRFABMS showed pseudomolecular ion peak at $\mathrm{m} / \mathrm{z}$ 326.0879, which is in consistence with the molecular formula of $\mathrm{C}_{14} \mathrm{H}_{16} \mathrm{NO}_{8}[\mathrm{M}+\mathrm{H}]^{+}$. Its IR spectrum showed absorption bands at 3419 and $1672 \mathrm{~cm}^{-1}$, which are characteristic for $\mathrm{OH}$ and amide moieties, respectively. The $500 \mathrm{MHz}{ }^{1} \mathrm{H}$ NMR spectrum $\left(D M S O-d_{6}\right) \quad$ displayed resonances for 15 protons including six exchangeable singlets (Table 1). From the counter plot of the ${ }^{1} \mathrm{H}-{ }^{1} \mathrm{H}$ COSY and HMQC 
Table 1: ${ }^{1} \mathrm{H}$ and ${ }^{13} \mathrm{C}$ chemical shift data of compound $1\left(\right.$ DMSO- $\left.d_{6}\right)$.

\begin{tabular}{|c|c|c|c|}
\hline No. & $\delta_{\mathrm{C}}$ (mult.) & $\delta_{\mathrm{H}}[$ mult., $J(\mathrm{~Hz})]$ & HMBC with $\mathrm{H}$ \\
\hline 1 & $70.20(\mathrm{~d})$ & 3.95 (br.s.) & $\mathrm{H}-3, \mathrm{H}-4 \mathrm{a}$ \\
\hline $\mathrm{HO}-1$ & - & 5.35 (br.s.) & \\
\hline 2 & $68.48(\mathrm{~d})$ & 4.27 (br.s.) & $\mathrm{H}-10 \mathrm{~b}$ \\
\hline $\mathrm{HO}-2$ & - & 4.82 (br.s.) & \\
\hline 3 & $73.29(\mathrm{~d})$ & 3.83 (br.s.) & $\mathrm{H}-1$ \\
\hline $\mathrm{HO}-3$ & - & 5.06 (br.s.)* & \\
\hline 4 & $69.98(d)$ & 3.72 (br.s.) & $\mathrm{H}-2, \mathrm{NH}$ \\
\hline $\mathrm{HO}-4$ & - & 5.06 (br.s.)* & \\
\hline $4 a$ & $50.51(\mathrm{~d})$ & $3.71(\mathrm{~m})$ & \\
\hline 5 & - & $7.50(\mathrm{~s})$ & \\
\hline 6 & $169.48(\mathrm{~s})$ & & $\mathrm{NH}, \mathrm{H}-10$ \\
\hline $6 a$ & $107.48(\mathrm{~s})$ & & $\mathrm{NH}, \mathrm{H}-10, \mathrm{H}-10 \mathrm{~b}$ \\
\hline 7 & $145.35(\mathrm{~s})$ & & $\mathrm{NH}, \mathrm{H}-10$ \\
\hline $\mathrm{HO}-7$ & - & 13.04 (br.s.) & \\
\hline 8 & $131.69(\mathrm{~s})$ & & $\mathrm{H}-10, \mathrm{OCH}_{2} \mathrm{O}$ \\
\hline 9 & $152.04(\mathrm{~s})$ & & $\mathrm{H}-10, \mathrm{H}-10 \mathrm{~b}, \mathrm{OCH}_{2} \mathrm{O}$ \\
\hline $\mathrm{OCH}_{2} \mathrm{O}$ & $101.75(\mathrm{t})$ & $6.04(\mathrm{~s}), 6.02(\mathrm{~s})$ & \\
\hline 10 & $97.67(\mathrm{~d})$ & $6.47(\mathrm{~s})$ & $\mathrm{H}-10 \mathrm{~b}$ \\
\hline $10 \mathrm{a}$ & $135.66(\mathrm{~s})$ & & $\mathrm{H}-4 \mathrm{a}, \mathrm{H}-10 \mathrm{~b}$ \\
\hline $10 \mathrm{~b}$ & $39.50(\mathrm{~d})$ & $2.95(\mathrm{~d}, 12.4)$ & $\mathrm{H}-1, \mathrm{H}-4, \mathrm{H}-10, \mathrm{NH}$ \\
\hline
\end{tabular}

*) Overlapped signals.

Table 2: ${ }^{1} \mathrm{H}$ and ${ }^{13} \mathrm{C}$ chemical shift data of compound $2\left(C D_{3} O D\right)$.

\begin{tabular}{|c|c|c|c|c|}
\hline No. & $\bar{~} \delta_{\mathrm{C}}$ (mult.) & 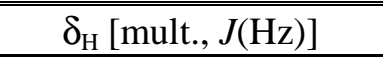 & HMBC with $\mathrm{H}$ & NOESY with $\mathrm{H}$ \\
\hline 1 & $75.31(\mathrm{~s})$ & & $\mathrm{H}_{2}-2, \mathrm{H}-3, \mathrm{H}-5, \mathrm{H}_{2}-6$ & \\
\hline 2 & $36.36(\mathrm{t})$ & $\begin{array}{c}2.15(\mathrm{dd}, 14.3,3.7) \\
2.05^{*}\end{array}$ & & \\
\hline 3 & $72.60(\mathrm{~d})$ & $5.30(\mathrm{~m})$ & $\mathrm{H}_{2}-2, \mathrm{H}-5$ & $\mathrm{H}-5$ \\
\hline 4 & $73.83(\mathrm{~d})$ & $3.63(\mathrm{dd}, 7.6,3.0)$ & $\mathrm{H}_{2}-2, \mathrm{H}-5, \mathrm{H}_{2}-6$ & $\mathrm{H}-5$ \\
\hline 5 & $68.60(\mathrm{~d})$ & $4.06(\mathrm{ddd}, 8.3,8.3,3.7)$ & $\mathrm{H}-3, \mathrm{H}-4, \mathrm{H}_{2}-6$ & $\mathrm{H}-3, \mathrm{H}-4$ \\
\hline 6 & $40.80(\mathrm{t})$ & $\begin{array}{c}2.03^{*} \\
1.97(\mathrm{dd}, 13.4,8.3)\end{array}$ & & \\
\hline 7 & $176.41(\mathrm{~s})$ & & $\mathrm{H}_{2}-2, \mathrm{H}_{2}-6, \mathrm{H}_{3}-8$ & \\
\hline 8 & $52.85(\mathrm{q})$ & $3.67(\mathrm{~s})$ & & \\
\hline $1^{\prime}$ & $127.91(\mathrm{~s})$ & & & \\
\hline $2^{\prime}$ & $115.09(\mathrm{~d})$ & 6.99 (br.s.) & & \\
\hline $3^{\prime}$ & $146.78(\mathrm{~s})$ & & H-2', H-5, & \\
\hline $4^{\prime}$ & $149.45(\mathrm{~s})$ & & H-2', H-5, H-6 & \\
\hline $5^{\prime}$ & $116.45(\mathrm{~d})$ & $6.70(\mathrm{~d}, 8.2)$ & & \\
\hline $6^{\prime}$ & $122.90(\mathrm{~d})$ & $6.89(\mathrm{~d}, 8.2)$ & & \\
\hline $7^{\prime}$ & $146.84(d)$ & $7.55(\mathrm{~d}, 16.0)$ & $\mathrm{H}-8^{\prime}$ & \\
\hline $8^{\prime}$ & $115.73(\mathrm{~d})$ & $6.25(\mathrm{~d}, 16.0)$ & & \\
\hline $9^{\prime}$ & $168.91(\mathrm{~s})$ & & $\mathrm{H}-7^{\prime}, \mathrm{H}-8^{\prime}$ & \\
\hline
\end{tabular}

*) Signals are partially overlapped. 
<smiles>O=C1N[C@H]2[C@H](O)[C@@H](O)[C@@H](O)[C@H](O)[C@]23CC2=CC4=C(OCO3)C(O)=C2[C@@H]14</smiles>

1

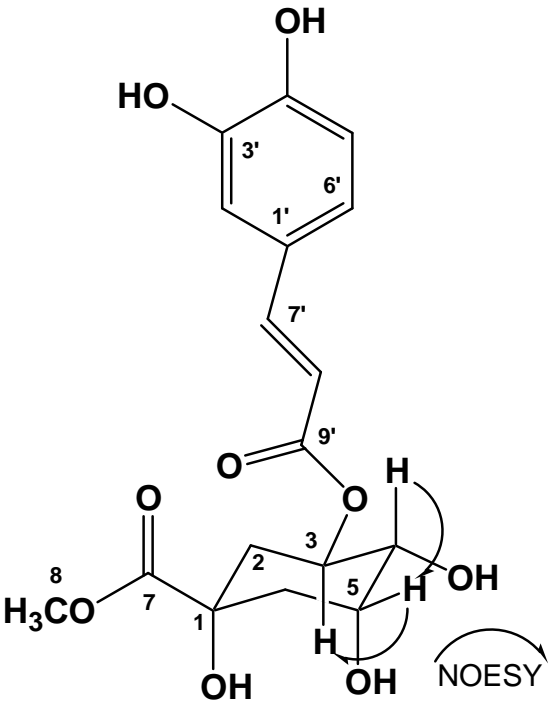

2

Fig. 1: Structures of the isolated compounds.

experiments, the existence of a single continuous spin-coupling system consisting of six resonating signals could be traced through the molecule of $\mathbf{1}$. The coupling system starts from the resonating signal at $\delta 3.95(\mathrm{H}-1)$ with coupling to the signals at $\delta 2.95(\mathrm{H}-10 \mathrm{~b})$ and $\delta$ $4.27(\mathrm{H}-2)$, which further couples to $\mathrm{H}-3$ at $\delta$ 3.83. Further coupling between $\mathrm{H}-3$ and $\mathrm{H}-4$ ( $\delta$ 3.72 ), between $\mathrm{H}-4$ and $\mathrm{H}-4 \mathrm{a}(\delta 3.71)$, and finally between $\mathrm{H}-4 \mathrm{a}$ and $\mathrm{H}-10 \mathrm{~b}$ was observed, completing the spin-coupling system. Further, COSY cross-peaks between H-1, H-2, H-3, H-4 and the exchangeable singlets at $\delta 5.34(\mathrm{HO}-1)$, 4.82 (HO-2), 5.06 (HO-3), and 5.06 (HO-4), respectively, were observed, confirming the tetrahydroxy substitution of the cyclic hexane ring of 1.

In addition, the ${ }^{1} \mathrm{H}$ NMR spectrum showed two one-proton singlets at $\delta 6.04$ and 6.02 for a methylenedioxy moiety and a singlet at $\delta 6.47$ for $\mathrm{H}-10$.

Furthermore, the exchangeable singlets at $\delta 13.04$ and 7.50 correspond to the phenolic $\mathrm{OH}$ at C-7 and the $\mathrm{NH}$ functionalities, respectively.

The ${ }^{13} \mathrm{C}$ NMR spectrum together with HMQC experiment revealed resonances for 14 carbons (Table 1) including six singlets, one triplet, and seven doublets. Unambiguous assignment of all protonated carbons was made possible from HMQC experiment, while the unequivocal assignment as well as the connectivities of the three rings of $\mathbf{1}$ were confirmed by HMBC experiment (Table 1). For Example, cross-peaks of H-10/C-6, NH/C-6 $(\delta$ 169.48), as well as H-10/C-6a, H-10b/C-6a, and $\mathrm{NH} / \mathrm{C}-6 \mathrm{a}(\delta 107.48)$ confirmed the assignments of these quaternary carbons. Similarly, the assignment of C-7, C-8, C-9, and C-10a was established from $\mathrm{HMBC}$ correlations and are listed in Table 1.

The above-mentioned data are in good agreement with the data reported for pancratistatin isolated previously from the roots and bulbs of Pancratium littorale ${ }^{7,8}$ (later reassigned as Hymenocallis littorale). ${ }^{9}$

\section{Compound 2}

Compound 2 was purified as a yellowish oil. Its positive HRFABMS showed a pseudomolecular ion peak at $\mathrm{m} / \mathrm{z} 369.1189$ which is consistent to the molecular formula of $\mathrm{C}_{17} \mathrm{H}_{21} \mathrm{O}_{9}[\mathrm{M}+\mathrm{H}]^{+}$. The IR spectrum showed absorption bands at 3420 and $1664 \mathrm{~cm}^{-1}$ corresponding to $\mathrm{OH}$ and ester moieties, respectively. Its $500 \mathrm{MHz}{ }^{1} \mathrm{H}$ NMR $\left(C D_{3} O D\right)$ spectrum revealed resonances for 15 protons (Table 2). Interpretation of the ${ }^{1} \mathrm{H}-{ }^{1} \mathrm{H}$ COSY and HMQC experiments showed the existence of three coupling systems. The first system 
includes the protons $\mathrm{H}-1 / \mathrm{H}_{2}-2 / \mathrm{H}-3 / \mathrm{H}-4 / \mathrm{H}-5 / \mathrm{H}_{2}-$ 6 . The second system (ABX system) is formed of the protons $\mathrm{H}-2^{\prime}, \mathrm{H}-4^{\prime}$, and $\mathrm{H}-6^{\prime}$, while the trans-coupled protons $\mathrm{H}-\mathrm{7}^{\prime}$ and $\mathrm{H}-\mathrm{8}^{\prime}(J=16.0$ $\mathrm{Hz})$ constitutes the third coupling system (AB system) (Table 2).

Interpretation of all protonated carbons within 2 was made possible from the HMQC experiment. The assignment of all quaternary carbons as well as the connectivities of the structural fragments of $\mathbf{2}$ were secured from HMBC correlations (Table 2). For example, HMBC correlations of $\mathrm{H}_{2}-2 / \mathrm{C}-7, \mathrm{H}_{2}-6 / \mathrm{C}-7, \mathrm{H}_{3}-$ 8/C-7 ( $\delta$ 176.41) and H-2'/C-3', H-5'/C-3', H$6^{\prime} / \mathrm{C}-3^{\prime}(\delta 146.78)$ established the assignments of these signals. Similarly, HMBC cross-peaks of $\mathrm{H}-2^{\prime} / \mathrm{C}-4^{\prime}, \mathrm{H}-5^{\prime} / \mathrm{C}-4^{\prime}, \mathrm{H}-6^{\prime} / \mathrm{C}-4^{\prime}$ ( $\delta$ 149.54), and $\mathrm{H}-7^{\prime} / \mathrm{C}-9^{\prime}, \mathrm{H}-8^{\prime} / \mathrm{C}-9^{\prime}(\delta$ 168.91) confirmed these assignments (Table 2).

The above-mentioned data are in good agreement with those reported for 3caffeoylquinic acid methyl ester ${ }^{10}$ and this is the first report of this compound in the family Amaryllidaceae.

The 2D NOESY experiment of $\mathbf{2}$ showed cross-peaks of H-3/H-5 and $\mathrm{H}-4 / \mathrm{H}-5$, supporting the configuration of the quinic acid moiety of $\mathbf{2}$ (Figure 1).

The existence of 3-caffeoylquinic acid methyl ester in Pancratium maritimum is noteworthy from the viewpoint of chemotaxonomy of the genus and family Amaryllidaceae.

\section{Biological evaluation of 1 and 2 1- Antitumor activity}

The in-vitro cytotoxicity of compounds 1 and 2 against HeLa cells were carried out according to Fukuzawa's method. ${ }^{11}$

\section{A) Preparation of test samples}

Tested samples for screening were prepared as follows. The polar crude extracts were dissolved in a mixture of $\mathrm{H}_{2} \mathrm{O} / \mathrm{MeOH}$ (1:1) to make a sample of $10 \mathrm{mg} / \mathrm{mL}$. The lipophilic/organic crude extracts were dissolved in $\mathrm{EtOH}$ to make a solution of 5 $\mathrm{mg} / \mathrm{mL}$. Column fractions and pure compounds were prepared by dissolving in $\mathrm{MeOH}$, DMSO, or water to afford final concentration of 1 $\mathrm{mg} / \mathrm{mL}$.

\section{B) Cell culture}

Human cervical carcinoma (HeLa) cells were maintained in adhesion on Petri dishes with Minimun Essential Medium (Gibco) supplemented with $10 \%$ fetal bovine serum, 2 $\mu \mathrm{g} / \mathrm{mL}$ gentamycin, $2 \mu \mathrm{g} / \mathrm{mL}$ antibioticantimicotic, and $0.3 \mathrm{M} \mathrm{NaHCO}_{3}$ (adjusted to $\mathrm{pH}$ 7.0-7.4 with $2 \mathrm{M} \mathrm{HCl}$ ). Subculture was made twice a week to maintain regular proliferation.

\section{C) Cytotoxicity test}

HeLa cells in a $200 \mathrm{~mL}$ of medium (cell concentration 625 cells $/ \mathrm{mL}$ ) were plated on 96well plates and allow to adhere at $37^{\circ}$ under an atmosphere of a mixture of air/ $\mathrm{CO}_{2}$ (95:5) for 24 hours. $2 \mathrm{~mL}$ of sample solution (concentration of $1 \mathrm{mg} / \mathrm{mL}$ ) was added, fold serial dilution was made, and the cells were incubated for $72 \mathrm{~h}$. Positive cytotoxicity control was also prepared using adriamycin (1 $\mathrm{mg} / \mathrm{mL}$ in DMSO).

The cell's viability was assessed through an MTT conversion method. After $72 \mathrm{~h}$, MTT $(1 \mathrm{mg} / \mathrm{mL}, 50 \mathrm{~mL})$ was added and the cells were incubated for an additional 3-4 $\mathrm{h}$. The mixtures of medium and MTT solutions were removed by aspiration, and diluted with 150 $\mathrm{mL}$ DMSO. The optical density of each well was examined with a microplate spectrophotometer at wavelength of $510 \mathrm{~nm}$. The $\mathrm{IC}_{50}$ values were estimated using SOFTmax Pro3.1.1 program or plotting \% inhibitions at tested concentrations on semi-log graph. Percent inhibition was calculated as $\{(\mathrm{A}-\mathrm{B}) / \mathrm{A} \times 100\}$, where $\mathrm{A}$ and $\mathrm{B}$ were absorbance of negative control and sample, respectively.

The cytotoxicity of compounds $\mathbf{1}$ and $\mathbf{2}$ against $\mathrm{HeLa}$ cells was evaluated as $\mathrm{IC}_{50}$ values and was presented in Table 3. Adriamycin was used as a positive cytotoxicity control. Pancratistatin (1) and 3-caffeoylquinic acid methyl ester (2) showed potent cytotoxicity against $\mathrm{HeLa}$ cells with $\mathrm{IC}_{50}=0.06$ and 1.0 $\mu \mathrm{g} / \mathrm{mL}$, respectively. The positive cytotoxicity control (Adramycin) showed $\mathrm{IC}_{50}$ value $=0.066$ $\mu \mathrm{g} / \mathrm{mL}$.

It is known that pancratistatin possesses a wide range of in-vitro and in-vivo cancer cell growth inhibitory as well as antiviral activities. ${ }^{9,12,13}$ But, this is the first report of its activity against HeLa cells. In addition, this is 
the first report of the cytotoxic activity of 3caffeoylquinic acid methyl ester.

Table 3: Cytotoxicity of compounds $\mathbf{1}$ and $\mathbf{2}$ against Hela cells $\left(\mathrm{IC}_{50}: \mu \mathrm{g} / \mathrm{mL}\right)$.

\begin{tabular}{|l|c|c|c|}
\hline \hline & Compound 1 & Compound 2 & Adriamycin* \\
\hline $\begin{array}{l}\text { HeLa } \\
\text { Cells }\end{array}$ & 0.06 & 1.0 & 0.066 \\
\hline
\end{tabular}

*Positive cytotoxicity control.

\section{2- Anti-Mycobacterium tuberculosis activity}

Compounds $\mathbf{1}$ and $\mathbf{2}$ were submitted to the Tuberculosis Antimicrobial Acquisition and Coordinating Facility (TAACF) of the Southern Research Institute for biological studies with Mycobacterium tuberculosis $\mathrm{H}_{37} \mathrm{Rv}$. In-vitro evaluation of antiMycobacterium tuberculosis activity of $\mathbf{1}$ and $\mathbf{2}$ was carried out according to Alamar Blue Assay. ${ }^{14}$ Below is a brief description of the assay:

\section{A) Alamar blue susceptibility test (MABA) ${ }^{14}$}

Antimicrobial susceptibility testing was performed in black, clear-bottomed, 96-well microplates (black view plates; Packaed Instrument Company, Meriden, Conn.) in order to minimize background fluorescence. Outer perimeter wells were filled with sterile water to prevent dehydration in experiment wells. Initial drug dilutions were prepared in either DMSO or distilled deionized water, and subsequent twofold dilutions were performed in $0.1 \mathrm{~mL}$ of 7H9GC (no Tween 80) in the microplates. BACTEC 12B-passaged inocula were initially diluted $1: 2$ in $7 \mathrm{H} 9 \mathrm{GC}$, and $0.1 \mathrm{~mL}$ was added to wells. Subsequent determination of bacterial titers yielded $1 \times 10^{6} \mathrm{CFU} / \mathrm{mL}$ in plat wells for $\mathrm{H}_{37} \mathrm{Rv}$. Frozen inocula were initially diluted 1:20 in BACTEC 12B medium followed by 1:50 dilution in 7H9GC. Addition of $1 / 10 \mathrm{~mL}$ to wells resulted in final bacterial titers of $2.0 \mathrm{x}$ $10^{5} \mathrm{CFU} / \mathrm{mL}$. Wells containing drug only were used to detect autofluorescence of compounds. Additional control wells consisted of bacteria only (B) and medium only (M). Plates were incubated at $37{ }^{\circ} \mathrm{C}$. Starting at day 4 of incubation, $20 \mathrm{~L}$ of $10 \mathrm{x}$ AlamarBlue solution (Alamar Biosciences/Accumed, Westlake, Ohio) and $12.5 \mathrm{~L}$ of $20 \%$ Tween 80 were added to one $\mathrm{B}$ well and one $\mathrm{M}$ well, and plates were reincubated at $37{ }^{\circ} \mathrm{C}$. Wells were observed at 12 and $24 \mathrm{~h}$ for a color change from blue to pink and for a reading of $\geq 50,000$ fluorescence units (FU). Fluorescence was measured in a Cytofluor II microplate fluorometer (PerSeptive Biosystems, Framingham, Mass.) in bottom-reading mode with excitation at $530 \mathrm{~nm}$ and emission at 590 $\mathrm{nm}$. If the B wells became pink by $24 \mathrm{~h}$, reagent was added to the entire plate. If the well remained blue or of $50,000 \mathrm{FU}$ was measured, additional $\mathrm{M}$ and $\mathrm{B}$ wells were tested daily until a color change occurred, at which time reagents were added to all remaining wells. Plates were then incubated at $37^{\circ} \mathrm{C}$, and results were recorded at $24 \mathrm{~h}$ post-reagent addition. Visual MICs were defined as the lowest concentration of drug that prevented a color change. For fluorometric MICs, a background subtraction was performed on all wells with a mean of triplicate $M$ wells. Percent inhibition was defined as $\{1-$ (test well FU/mean FU of triplicate B wells) $\mathrm{x} 100\}$. The lowest drug concentration effecting an inhibition $\geq 90 \%$ was considered the MIC.

\section{B) Statistical analysis}

All analysis were performed with the program SAS (SAS Institute Inc., Cary, N.C.). Correlation coefficient were defined according to Spearman for ranked data analysis and Pearson for raw data analysis to determine differences between the BACTEC system and the MABA either fluorometrically or visually for determination of MIC. ${ }^{15}$ A general linear model procedure using analysis of variance of ranked data was performed for each of the three variables of MIC generation to determine significant differences between the replicate comparisons of the four experiments. Tukey's Studentized range test was also used for pairwise post hoc comparison of variable analysis of ranked measure for significant differences among techniques of MIC determination and for differences between techniques for individual antimicrobial agents for each bacterial strain. Significance was determined at $P \leq 0.05$.

\section{C) Bacterial strains and growth conditions}

M. tuberculosis $\mathrm{H}_{37} \mathrm{Rv}$ ATCC 27294 $\left(\mathrm{H}_{37} \mathrm{RV}\right)$, was obtained from the American 
Type Culture Collection (Rockville, Md.). For the first three (of four) replicate experiments, $\mathrm{H}_{37} \mathrm{Rv}$ inocula were first passaged in radiometric $7 \mathrm{H} 12$ broth (BACTEC 12B; Becton Dickinson Diagnostic Instrument Systems, Sparks, Md.) until the growth index (GI) reached 800 to 999.

For the fourth replicate experiment, $\mathrm{H}_{37} \mathrm{Rv}$ was grown in $100 \mathrm{~mL}$ of Middlebrook 7H9 broth (Difco, Detroit, Mich.) supplemented with $0.2 \%$ (vol/vol) glycerol (Sigma Chemical Co., Saint Louis. Mo.), 10\% (v/v) OADC (oleic acid, albumin, dextrose, catalase; Difco), and $0.05 \%$ (v/v) Tween 80 (Sigma). The complete medium was referred to as 7H9GC-Tween. Cultures were incubated in $500-\mathrm{mL}$ nephelometer flasks on a rotary shaker (New Brunswick Scientific, Edison, N.J.) at $150 \mathrm{rpm}$ and $37{ }^{\circ} \mathrm{C}$ until they reached an optical density of 0.4 to 0.5 at $550 \mathrm{~nm}$. Bacteria were washed and suspended in $20 \mathrm{~mL}$ of phosphate-buffered saline and passed through an 8- m-pore-size filter to eliminate clumps. The filtrates were aliquoted, stored at $-80^{\circ} \mathrm{C}$, and used within 30 days.

Compound 1 was found to effect moderate inhibitory activity (48\%) against $M$. tuberculosis $\mathrm{H}_{37} \mathrm{Rv}$ at a concentration of 12.5 $\mu \mathrm{g} / \mathrm{mL}$, whereas 2 inhibited $43 \%$ of the mycobacterial growth at the same concentration.

This is the first report of anti-tuberculosis activity of an Amaryllidaceae alkaloid (pancratistatin) and for 3-caffeoylquinic acid methyl ester.

\section{Acknowledgment}

In-vitro antimycobacterial evaluations of compounds $\mathbf{1}$ and $\mathbf{2}$ were carried out the U.S. Tuberculosis Antimicrobial Acquisition and Coordinating Facility (TAACF), NIAID/NIH under the Research and Development Contract No. 1540 with Diaa Youssef. We gratefully appreciate the taxonomic identification of the plant material by Prof. A. Fayed at Assiut University. $500 \mathrm{MHz}$ NMR and HRFABMS spectral determinations were kindly provided by Prof. Dr. N. Fusetani at the University of Tokyo. The HeLa (TKG0331) cells were a donation of the Institute of Development, Aging and Cancer of Tohoku University, Japan.

\section{REFERENCES}

1- D. T. A. Youssef, J. Nat. Prod., 64, 839 (2001).

2- D. T. A. Youssef and A. A. Khalifa, Pharmazie, 56, 818 (2001).

3- D. T. A. Youssef, Pharmazie, 54, 535 (1999).

4- D. T. A. Youssef and A. W. Frahm, Planta Med., 64, 669 (1998).

5- D. T. A. Youssef, M. A. Ramadan and A. A. Khalifa, Phytochemistry, 49, 2579 (1998).

6- A. A. Ali, M. A. Makboul, A. A. Attia and D. T. Ali, Phytochemistry, 29, 625 (1990).

7- G. R. Pettit, V. Gaddamidi, G. M. Cragg, D. L. Herald and Y. Sagawa, J. Chem. Soc., Chem. Commun., 1693 (1984).

8- G. R. Pettit, V. Gaddamidi and G. M. Cragg, J. Nat. Prod., 49, 995 (1986).

9- G. R. Pettit, N. Melody and D. L. Herald, J. Org. Chem., 66, 2583 (2001).

10- L. Peng, S. Mei, B. Jiang, H. Zhou and H. Sun, Fitoterapia, 71, 713 (2000).

11- S. Fukuzawa, S. Matsunaga, N. Fusetani, J. Org. Chem., 60, 608 (1995).

12- B. Gabrielsen, T. P. Monath, J. W. Huggins, D. F. Kevauver, G. R. Pettit, G. Groszek, M. Holingshead, J. J. Kirsi, W. M. Shannon, E. M. Schubert, J. DaRe, B. Ugarkar, M. A. Ussery and M. J. Phelan, J. Nat. Prod., 55, 1569 (1992).

13- B. Gabrielsen, T. P. Monath, J. W. Huggins, J. J. Kirsi, M. Holingshead, W. M. Shannon and G. R. Pettit, In Natural Products as Antiviral Agents, C. K. Chu, H. G. Cutler, Eds., Plenum: New York, pp 121-135 (1992).

14- L. Collins and S. G. Frazblau, Antimicrob. Agents Chemother. 1997, 41, 1004-1009.

15- R. G. D. Steel and J. H. Torrie, Principles and procedures of statistics. A biometrical approach, $2^{\text {nd }}$ ed. McCraw-Hill, New York, N.Y., p 272-284 and 550-551 (1980). 